\title{
A Precariedade Humana e \\ A EXISTÊNCIA EsTILIZADA
}

Rita Paiva ${ }^{1}$

RESUMO: Este artigo tematiza o desamparo vivenciado pela consciência ante a ausência de bases sólidas para seus anseios de felicidade e para suas representações simbólicas. Com esse propósito, toma como objeto de reflexáo um dos ensaios filosóficos de Albert Camus, $O$ mito de Sisifo, equacionando a possibilidade de uma ética que estilize a vida, sem que se minimize a dolorosa precariedade da existência humana. Posteriormente, em diálogo com alguns textos de M. Foucault, a reflexão procura estabelecer os vínculos possíveis entre a ética camusiana e a ética como uma estética da existência, tal como pensada entre os gregos antigos.

PALAVRAS-CHAVE: Absurdo. Estética. Ética. Existência.

\section{A CONDUTA ABSURDA: VIVER SEM CONCILIAÇÃO}

A experiência individual da mortalidade consiste numa temática recorrente nos ensaios filosóficos de Albert Camus. Particularmente, em $O$ mito de Sísifo, o autor observa que vivemos como se a finitude não nos espreitasse. Lembra, no entanto, que há sempre o momento em que contemplamos o horizonte de aniquilamento para o qual nos lançamos. Quando esse instante advém, não há projeto, convicção humana que não soçobre; não há ordem que permaneça incólume ao caos. Certamente, o autor não problematiza especificamente a experiência da morte, mas alude ao pensamento e aos sentimentos que ela pode suscitar, quando a consciência ousa raciocinar lucidamente acerca de sua condição (cf. MAUROIS, 1965).

Ante o espectro candente da finitude, a ausência de respostas para a paixão mais visceral que nos habita - a questáo do sentido da existência -, ou a impossibilidade de superar a precariedade a que estamos destinados, pode transformar o existir em algo profundamente atroz. Náo surpreende, pois, que

\footnotetext{
${ }^{1}$ Professora de Filosofia na EFLCH-Universidade Federal de São Paulo.
} 
a consciência, ao elucidar-se a propósito de sua condição absurda, flerte com o suicídio, o qual figura inicialmente como a única alternativa tangível, passível de amenizar o sofrimento, brindando-nos com uma certa dose de coerência e de lógica. Sob essa perspectiva, para o pensamento que conscientemente vislumbra a desmesura mundana, o nada e a impossibilidade de justificação do existir, a alternativa razoável residiria unicamente na morte voluntária, a qual nos libertaria definitivamente da condição de condenados aos vaticínios inelutáveis que o destino nos reserva. Não obstante, nesse seu ensaio, mais do que afirmar uma correlação necessária entre o absurdo e o suicídio, Camus pretende investigar e avaliar com rigor as possibilidades da atitude humana ante a absurdidade. Destarte, considera que a desmedida e o desarrazoado mundano por si sós não fundamentam o absurdo de existir. Não há absurdidade fora do espírito humano, ou sem o embate entre ele e a realidade que o circunda; vemos, assim, que a morte voluntária opera propriamente a desaparição do objeto a ser perscrutado. "A primeira e, no fundo, única condição das minhas investigações é preservar aquilo que me oprime, respeitando em consequência o que julgo essencial nele" (CAMUS, 2004, p. 46). A investigação do autor ultrapassa, por conseguinte, a alternativa do suicídio. Camus assevera: o mais terrível dos sofrimentos poderá ser suportado, se for justificado; mas, sem explicação, os homens em geral não suportam viver. Inventam assim alternativas que possam mitigar o sofrimento e que caucionem sua crença e sua insistente busca de razóes justificadoras para sua existência. Numa palavra, os homens trapaceiam ante o intolerável. A crítica camusiana aos subterfúgios de todo aspecto - como a fé e a esperança -, aos quais homens e mulheres, em sua variabilidade cultural, recorrem para contemporizar com a mais dolorosa de suas paixóes, é contundente em $O$ mito de Sísifo: "Esperança de uma outra vida que é preciso 'merecer', ou truque daqueles que vivem não pela vida em si, mas por alguma idéia que a ultrapassa, sublima, lhe dá um sentido e a trai” (CAMUS, 2004, p. 22).

Somente o ódio à vida, argumenta o autor, conduz a essas esperanças que acenam com uma felicidade sobre-humana. Inversamente, a procura do ensaísta é pela possibilidade de um modo de existir que prescinda de máscaras; que aceite, até em sua mais íntima dimensão, o sofrimento de viver sem respostas para os anseios mais pungentes da consciência. Certamente, a lucidez a respeito da absurdidade pode incitar ao ato suicida, mas pode também despertar uma obstinação: o desejo de viver intensamente, à revelia da inviabilidade dos sonhos desvairados de unidade. Esta seria, propriamente, a atitude do homem absurdo. 
O indivíduo que recusa a estratégia da trapaça incorpora visceralmente o dilema entre a consciência que deseja conformidade, lógica, significados inteligíveis e o mutismo de um mundo desarrazoado: "Posso negar tudo desta parte de mim que vive de nostalgias incertas, menos esse desejo de unidade, esse apetite de resolver, essa exigência de clareza e coesão" (CAMUS, 2004, p. 63). Mesmo o homem lúcido desespera ante a insensatez da ordem que o ultrapassa. Todavia, ele não se resigna; sua enfática adesão ao absurdo é simultaneamente atestada e nutrida pela seiva da revolta. Advoga Camus: "Por isso, uma das poucas posturas filosóficas coerentes é a revolta, o confronto perpétuo do homem com sua própria escuridão" (CAMUS, 2004, p. 64). A consciência revoltada deseja apreender racional e lucidamente o absurdo no qual se encontra inserta. Sua ousadia consiste em morrer sem jamais se reconciliar. A revolta coincide com um olhar trágico sobre o mundo: "Para um homem sem antolhos não há espetáculo mais belo que o da inteligência às voltas com uma realidade que a supera" (CAMUS, 2004, p. 67). Daí decorre que o assentimento radical do absurdo tem sua primeira consequência nesse espírito de revolta que é ainda atravessado pelos anseios intensos da loucura unificante, sem que se obscureça a sua lucidez quanto às interdiçóes absolutas e definitivas que a vida impóe a esse desejo.

O espírito assim revoltado experiencia uma liberdade estritamente humana. Novamente, Camus:

[...] se o absurdo aniquila todas as minhas possibilidades de liberdade eterna, também me devolve e exalta, pelo contrário, minha liberdade de ação. Tal privação de esperança e de futuro significa um crescimento na disponibilidade do homem. (CAMUS, 2004, p. 68).

Ao elaborar um projeto, um amanhã para sua existência pessoal, embora o horizonte aí configurado nada tenha de heróico, o homem comum supốe que é livre para determinar seus caminhos, para engendrar significações que alicercem sua existência, ainda que o destino e as evidências contraditem sistematicamente tais veleidades. É a crença ilusória na unidade entre o sonho humano e o mundo que aí se instaura. Essa é também a esperança que se esboroa com a consciência absurda; não há elo entre o pensamento e o real que persista, quando a lucidez acerca da finitude irrompe, revelando a insuperável clivagem entre o homem e seu cenário. Irrigado pela liberdade que a consciência absurda proporciona, emancipado de toda e qualquer esperança, 
o homem absurdo amplia sua abertura para a multiplicidade. Consuma, pois, sua liberdade, bem como sua opção pela vida.

Sem dúvida, o sujeito que vislumbra os limites temporais dentro dos quais sua liberdade pode ser exercida, mais do que tudo, anseia por viver. Não uma vida norteada pelos parâmetros da conservação, mas uma vida que se pauta substancialmente pela abertura para experiências viscerais. O homem absurdo será, por conseguinte, aquele que mais disponibilidade apresenta para as ofertas que a vida lhe faz. Resistindo às seduçôes que visam ao obscurecimento da consciência, dispóe-se para a vida sem sacrificá-la em nome de uma vida outra que acene com a realização de seus sonhos mais arcaicos. Para ser consumado, esse sim à vida, em sua contundência, o qual implica a inclusão de suas antinomias, de suas adversidades, ou seja, de tudo o que nela fascina, encanta e mortifica, como o diria Nietzsche, solicita a renúncia ao sentido. Compreendemos, assim, a assertiva do autor: a vida é mais apaixonadamente vivida se destituída de significaçóes. Inequivocamente, para o indivíduo que se recusa a hostilizar a vida, o destino delineia-se como uma seara estéril e aterradora. Paradoxalmente, entretanto, o enfrentamento desse horizonte revela-se como a premissa necessária para o alcance do sonho mais recôndito, qual seja, o de ser feliz. A experiência da felicidade parece improvável, quando lançamos sobre a existência um olhar desencantado. Contudo, para Camus, ou para o homem absurdo, ao contrário de toda a expectativa comumente perseguida, não é na representação do absoluto ou na supressão do vazio que nos assola que reside a felicidade. Inversamente, postula o autor, é a absurdidade de nossa condição que torna factível o experiência da felicidade. $\mathrm{O}$ assentimento da vida em suas antinomias mais profundas opera um alargamento da condição de homem; uma felicidade humana - e não sobre-humana - deve, pois, ser vislumbrada.

Ao romper com toda expectativa de redenção, sem que isto resulte num espírito resignado, o homem absurdo emancipa-se de toda idolatria, enfrenta seu tormento, humaniza seu destino. $\mathrm{O}$ assentimento visceral e doloroso de sua condição propicia que ele se torne autor consciente e radical dos seus dias. Não quer isto dizer que ele possa burlar o destino ou controlar os vaticínios a ele designados pelas forças atrozes e desmedidas que o ultrapassam, o que o lançaria na lógica das trapaças, de uma falsa liberdade. Significa que, liberto do amanhā, dos ideais que contemplam suas recônditas e tenebrosas nostalgias, ele vivencia mais radicalmente sua condição de sujeito. Novamente, o autor: "Tudo o que faz o homem trabalhar e se agitar utiliza a esperança. $\mathrm{O}$ único 
pensamento não enganoso é, entấo, um pensamento estéril. No mundo absurdo, o valor de uma noção ou de uma vida se mede por sua infecundidade" (CAMUS, 2004, p. 81).

Ao definir, desse modo, a postura do homem absurdo ante a desmesura do mundo, Camus parece apresentar-nos uma alternativa de subjetivação, de construção de si num mundo incólume aos clamores da razáo. É lícito, logo, conjeturar que o desenlace para o qual converge a investigação encetada em $O$ mito de Sisifo, preconiza uma moral ou, antes, uma ética fundada na absurdidade. Por outro lado, cumpre interrogar: a consciência absurda revoltada, livre e apaixonada, tal como Camus a descreve no ensaio, ao apontar para uma ética que divinize a vida em todos os seus aspectos ensejaria também uma estética? Mais claramente, ao instalar-se limpidamente na consciência, o absurdo impregnaria a consciência com um afă criador, transformando-a no agente de uma forma de existir em que vida e arte se amalgamam?

\section{ESFORÇO DE SUBJETIVAÇÃo E ESTILO DE EXISTIR}

É lícito asseverar que, para Camus, a moral do homem absurdo se inscreve numa forma de subjetivação - numa ética, portanto - na qual o indivíduo se empenha na construção de si, independentemente dos códigos socialmente fixados. Salienta Camus:

Não que a nostalgia lhe seja alheia [ao homem absurdo]. Mas prefere a ela sua coragem e seu raciocínio. A primeira lhe ensina a viver sem apelo e a satisfazer-se com o que tem, o segundo lhe ensina seus limites. (CAMUS, 2004, p. 80).

Entretanto, não há como escapar aos apelos de unidade, identidade e consonância que ressoam do fundo da alma ou da psique; eles perseveram mesmo que a consciência desperte. Manter-se fiel à regra absurda não implica livrar-se desses anseios, o que só ocorreria numa instância não humana; significa antes não sucumbir aos sortilégios, às promessas de redenções alienantes. Esse olhar lúcido assume as precariedades que chancelam a condiçáo humana ante um mundo desmedido e tem como corolários inexoráveis a revolta, a liberdade alargada e a paixão pela vida. Eis a moral - ou a ética? - do homem absurdo.

A moral assim configurada remete-nos aos gregos e, também, a Michel Foucault. Em seus dois últimos livros, $O$ uso dos prazeres e $O$ cuidado de si, que 
se incluem num projeto mais amplo, qual seja, $A$ história da sexualidade, Michel Foucault aborda os comportamentos sexuais na Antiguidade sob um ângulo bastante peculiar. Ou seja, seu intuito consiste em esclarecer o modo pelo qual esses comportamentos foram equacionados em relação a uma arte de viver. Segundo o autor, no âmbito dessa cultura e desse período histórico (século IV a.C. a século III d.C.), a reflexão sobre os diferentes tipos de conduta desdobrase na problemática da estilização das relações humanas, seja no que concerne à relação do indivíduo consigo mesmo, seja na sua relação com os outros.

São duas as características dessa moral, definitivamente não dominante. Primeiramente, a preocupação com os problemas religiosos, com a vida após a morte ou com a intervenção divina no destino humano é suplantada por um interesse bastante verticalizado na própria conduta e nas relaçóes intersubjetivas. A questáo religiosa separa-se dessa ética. Por outro lado, a forma pela qual as pessoas são instigadas a reconhecer suas obrigaçóes morais não é regida por uma lei transcendente revelada nas escrituras ou por uma ordem cosmológica que se impóe universalmente a todos ou, tampouco, por uma lei racional, no sentido kantiano. Independentemente da coerção religiosa ou dos constrangimentos provenientes da lei civil, para o homem desse tempo, é absolutamente necessária a escolha de sua conduta. É no plano da autonomia que essa moralidade nos insere.

A inspeção foucaultiana acerca da ética sexual que se instaura entre esses homens finda por revelar que a conduta prevalecente nessa cultura não prima pela liberalidade ou por uma tolerância exacerbada em relação às paixóes. Inversamente, sustenta Foucault, essa conduta pauta-se por uma vontade de regra que persegue não apenas uma forma, mas também a austeridade. As paixóes podem conduzir à hybris, daí a urgência de certas regras que viabilizassem o autogoverno, o domínio de si. É preciso frisar, no entanto, que a conduta austera era perseguida como uma particularidade que passava ao largo da moral estabelecida ou de pretensôes universalizantes; assim, comportamentos erigidos em grupos diversos resultavam em esquemas diferenciados que se tornavam peculiares por uma proposta de rigor, pelas sugestôes de estilos moderados de conduta. $\mathrm{O}$ texto nos instrui:

Estamos bem longe de uma forma de austeridade que tende a sujeitar todos os indivíduos da mesma forma, [...], sob uma lei universal [...]. As poucas grandes leis comuns - da cidade, da religiáo, ou da natureza - permanecem presentes, mas como se elas desenhassem ao longe um círculo bem largo no interior do qual o pensamento prático deve definir o que convém fazer. E para isso ela náo tem necessidade de algo como um texto que faça as leis, 
mas de uma techné ou de uma "prática" de um savoir-faire que, levando em conta os princípios gerais, guie a ação no seu próprio momento, de acordo com o contexto e em função de seus próprios fins. Portanto, não é universalizando a regra de sua ação que, nessa forma de moral, o indivíduo se constitui como sujeito ético; é ao contrário, por meio de uma atitude e de uma procura que individualiza sua ação que modulam e que até podem dar um brilho singular pela estrutura racional e refletida que lhe confere. (FOUCAULT, 1988, p. 59).

Essas consideraçôes facultam-nos a vislumbrar que a austeridade do agente em relação aos próprios desejos, no intuito de controlá-los e experienciá-los equilibradamente, não se justifica em nome de uma norma moral ou religiosa, mas pela proposição de agir admiravelmente. $\mathrm{O}$ horizonte da conduta ética reside, pois, no alcance da "soberania sobre si mesmo", numa genuína elaboração de si. Daí deriva a imperiosa necessidade de educar o corpo na sua relação com os afetos. A pretensão de conferir uma forma extraordinária à existência solicita um exercício contínuo de autodomínio no que tange aos movimentos das paixóes; parafraseando o autor: um cuidado de si.

Não obstante, Foucault nos alerta: esse "cuidado de si", que assume extrema relevância, não equivale a uma obsessão ou fascinação consigo mesmo; essa prática relaciona-se antes com uma cultura da moderação, ${ }^{2}$ com uma certa forma de ascetismo que viabilizaria o domínio - não a erradicação - das próprias paixóes. O modo de assujeitamento vigente entre os gregos ou seja, o modo pelo qual o indivíduo se relaciona singularmente com um código moral objetivo - consistia, portanto, numa escolha político-estética. Para realizá-la, desenvolveram uma série de técnicas que, uma vez exercitadas,

\footnotetext{
${ }^{2}$ A noção de moderação ou de ética como o justo meio está fortemente presente na ética aristotélica. $\mathrm{O}$ objetivo último da ética, segundo Aristóteles, reside na felicidade. Enquanto um bem autossuficiente, a felicidade distingue-se de um estado emocional subjetivo; ela consiste antes numa atividade da alma em consonância com a virtude; para ser alcançada, exige, portanto, o trabalho de uma vida inteira, um exercício contínuo e cotidiano. A tarefa ética impóe, por conseguinte, a educaçáo dos desejos e das paixôes. Em Aristóteles, a racionalidade e as paixôes devem harmonizar-se, de sorte que o comportamento humano se afaste da desmedida, do excesso, enfim, do vício, e se aproxime da virtude. Atentemos, porém: ser virtuoso nada tem a ver com uma inclinação natural, torna-se virtuoso em função de uma disposição, do hábito adquirido para a moderação: "O que é a virtude? A medida entre os extremos contrários, a moderação entre os dois extremos, o justo meio, nem excesso nem falta. [...] Moderar é pesar, ponderar, equilibrar, deliberar, é a ação que institui a medida, o métron, para aquilo que, por si mesmo e em si mesmo, não possui ou nâo conhece medida ou limite. $\mathrm{Na}$ ética aristotélica, a medida moderadora é o médio, mesón, ou mesótes, o justo meio. A ética é, pois, a ciência pratica da moderação, ou como diz Aristóteles, da prudência (phrónesis). A virtude é virtude de caráter ou força do caráter educado pela moderação para o justo meio ou a justa medida" (CHAUÍ, 2002, p. 446).
} 
conduziam ao almejado domínio de si. Mais claramente, essa ética peculiar, além de operar uma forte ligação entre o prazer e o desejo, traz em seu cerne uma preocupação com o bem viver e, por conseguinte, com as práticas que poderiam conduzir a esse fim. Em $O$ Uso dos Prazeres, o autor procura compreender as estratégias instauradas pelos gregos para que o controle de si e a bela conduta fossem efetivamente alcançados, e as designou por técnicas de si mesmo. Justifica-se, assim, o exercício contínuo da meditação, do exame de consciência, do silêncio e, posteriormente, da escrita. ${ }^{3}$

Sob essa perspectiva, Foucault considera que entre os antigos predominou uma moral orientada para a ética, cuja dinamicidade repousava nas formas de subjetivaçãó . Obviamente, o autor não advoga em prol da inexistência da regra nessa cultura, mas, nela, a moral consiste antes numa instância crucial da existência individual e coletiva sem que seja necessariamente secundada por um sistema jurídico, por uma autoridade ou por estratégias disciplinares. Ora, numa situação em que os indivíduos não

\footnotetext{
${ }^{3}$ À guisa de exemplo, a prática dos registros públicos ou individuais era utilizada como livros de vida ou como guias de conduta por esse segmento minoritário. Tais textos eram compostos por citaçôes, fragmentos de pensamentos, modelos comportamentais vistos ou ouvidos em relatos; materializavam, pois, uma espécie de memória coletivamente produzida e compunham um conjunto de textos práticos, elaborados de modo a se tornarem objeto de reflexão e instrumento para a conduta do dia-a-dia: "O papel desses textos era o de serem operadores que permitiam aos indivíduos interrogar-se sobre sua própria conduta, velar por ela, formá-la, conformar-se, eles próprios como sujeitos éticos, eles participam de uma função "eto-poética" (FOUCAULT, 1988, p. 16).

${ }^{4}$ No intuito de diferenciar moral e práticas de si, Foucault inicia sua reflexão problematizando a definição clássica. Alude, pois, à concepção de moral como o conjunto de comportamentos, regras e valores que norteiam a conduta dos indivíduos e das coletividades e que são interiorizados no processo de socialização por instituiçôes fundamentais da sociedade. Observa, contudo, que, por vezes, a transmissão de regras e valores que tornam tangível a moral social ocorre de modo pouco claro e sistemático, de sorte que os elementos que a compóem nem sempre se apresentam sintonizados; eles podem se contrapor, anularemse e dar lugar a formas diferenciadas de incorporação de seus preceitos. Assim, entre as regras morais e os comportamentos individuais por elas regidos instaura-se um interregno de liberdade em que o agente escolhe a maneira de relacionar-se com essas referências, em face das circunstâncias que se lhe desenham. Essa relação pode engendrar formas de conduta que náo aquelas objetivadas pela regra e que, no limite, escapam aos perfis a elas subjacentes. As diferentes formas de se relacionar com uma normatividade instituem, enfim, uma moralidade social que Foucault denomina determinação da substância ética. É nessa fenda entre a determinaçáo da regra moral e as condutas resultantes do seu assentimento e de sua recusa que Foucault situa a problemática da ética. Mesmo que a moralidade produzida pela sociedade ou pela cultura fixe os modos de comportamento, catalogando-os como aceitáveis e inaceitáveis, existe uma instância em que o indivíduo, ao submeter a regra ao crivo do seu juízo, escolhe sua conduta e exercita sua condiçấo de sujeito moral e autor de si mesmo. Por esse prisma, a moral se delineia na relação do indivíduo com a regra, enquanto a ética se constitui mais propriamente na relação do indivíduo com ele mesmo, quando se abre a esfera em que deve ser escolhida a forma singular que a conduta individual assumirá, ainda que sob a égide de um código objetivo.
} 
sejam constrangidos por leis objetivas, ou seja, sintam-se livres em relação a normas de caráter externo, aflora, argumenta Foucault, uma necessidade de dar à vida e ao comportamento individual uma forma específica, na qual se exerce o governo de si. Consequentemente, a escolha subjetiva não se justifica pelo intuito de ser recompensada com uma vida após a morte - como ocorrerá no registro cristão -, mas pelo desejo de atribuir à sua vida valores exemplares, dotando-a de uma coloração peculiar.

Esses indivíduos, ao perseguirem formas de subjetivação ímpares, procediam antes por avaliação da coerência entre a regra, a ação e determinados modos de existência, já que a ética, sob o enfoque foucaultiano, concerne a regras que, em vez de coagir, sugestionam e elucidam acerca da relaçâo entre as atitudes que assumimos e os modos de existência, os estilos de vida que a partir daí se delineiam. (cf. FOUCAULT, 1988, p. 15). Vislumbramos, assim, que a contínua problematização sobre as estratégias - techné - necessárias para cuidar de si que caracterizavam esta ética, visava, primordialmente, a conferir à vida dos sujeitos os atributos da beleza e do equilíbrio. Tratava-se enfim de inventar um estilo de existir. Por esse prisma, o conjunto de práticas voltadas para o domínio de si converge para uma forma de existência a partir da qual os indivíduos, além de estabelecer as regras que moldam sua conduta, "[...] procuram se transformar, modificar-se em seu ser singular e fazer de sua vida uma obra que seja portadora de certos valores estéticos e responde a certos critérios de estilo" (FOUCAULT, 1988, p. 15). Distante da moral, as formas de subjetivação, aí prevalecentes, alinham-se ao registro ético e estético, porque instauram modos de viver, formas de agir que não se justificam nem se esgotam nos códigos objetivos. Decorre dessa constatação que os gregos, assinala Deleuze, "[l]onge de ignorarem a interioridade, a individualidade, a subjetividade, eles inventaram o sujeito, mas como uma derivada, como o produto de uma subjetivação. Descobriram a existência estética, isto é, [...] a relação consigo, a regra facultativa do homem livre" (DELEUZE, 1988, p. 108). Sob essa perspectiva, no que tange a esse segmento da cultura grega, a esfera da vida na qual os valores estéticos devem prevalecer é aquela que concerne à própria existência. Por conseguinte, as regras que regem a ação moral destituem-se de um caráter coercitivo e tornam-se facultativas, resultando numa produção estilizada da existência.

Desenvolve-se, assim, uma forma de conduta específica e quase marginal que será interpretada por Foucault como uma "arte da existência", uma ética que é também uma estética, com a qual esses homens não apenas exercitavam 
a condição de sujeitos de sua própria vida, mas se empenhavam também em dotá-la de uma forma singular. Numa palavra, essa pequena elite é motivada pelo desejo de viver uma vida bela que possa perdurar na memória alheia como uma obra digna de apreciação e de admiração. Urge, portanto, interrogar de que modo a ética como estética da existência, tal como experienciada pelos antigos, se correlaciona com a moral proposta por Camus, em $O$ mito de Sisifo.

Ao aludir aos fundamentos da moral absurda, Camus estabelece de modo bastante geral e amplo os princípios que regem uma conduta consoante à absurdidade. Obviamente, a imperiosa necessidade de que eles sejam incorporados não se inscreve em instituições formais, porém, permanecendo numa seara foucaultiana, na relaçâo do indivíduo consigo mesmo. É a partir de suas próprias determinaçóes que um indivíduo logra manter-se na absurdidade; é preciso que ele exija de si próprio a resistência à suas paixóes de unidade, ao seu desejo de sentido para que sua conduta se peculiarize por uma ética genuinamente absurda. Consequentemente, a dinâmica dessa moral repousa náo em códigos objetivos ou em instituiçóes cristalizadas, mas em formas específicas de subjetivação. É certo que Camus não se refere a técnicas de vida, não propóe explicitamente um cuidado de si, conquanto não menospreze a importância da disciplina. Manter a tensão da consciência entre a lucidez e os apelos que emanam dos confins do eu exige uma determinaçáo da qual poucos são capazes: "Há muita esperança tenaz no coração humano. Os homens mais despojados acabam aceitando a ilusão" (CAMUS, 2004, p. 118). É preciso que o sentimento de revolta contra a condição humana não vacile nem se ausente por nenhum momento da consciência desperta, caso contrário, cede-se à sedução dos horizontes redentores. Daí a necessidade do esforço contínuo e de uma árdua disciplina que viabilize o controle dessa paixão virulenta. A criação de uma ética absurda requer profunda abnegação, o compromisso da vontade. Para ela, o futuro é estéril; logo, a coerência exigida pela absurdidade consiste numa ascese para nada. Torna-se, pois, crucial uma determinação rigorosa, uma luta constante consigo mesmo, uma educação permanente de si. Nesse sentido, seria lícito considerar que a moral absurda se correlaciona intimamente com as práticas de si às quais Foucault se refere. Com a disciplina aí exercitada, que paradoxalmente resulta numa ampliaçáo da liberdade e na abertura apaixonada para a vida, o indivíduo, parafraseando Foucault, aprimora, transforma, constrói o seu próprio ser, inaugurando uma subjetividade ímpar e original. Aqui, é pertinente o comentário de Deleuze: "A luta pela subjetividade se apresenta entáo como direito à diferença e direito à variaçâo, à metamorfose” (DELEUZE, 1988, p. 113). 
Destarte, orientando-se pelos preceitos básicos da moral absurda, os agentes, no intervalo de liberdade que se desenha entre os fundamentos e a ação singular - findam por instaurar - ou inventar - diferentes modos de ser, múltiplas subjetividades. Abre-se aqui a fenda para a emergência de distintos sujeitos morais que, em sua variabilidade, comungam a mesma substância ética. Ora, é exatamente no processo de assujeitamento, no qual se busca o ajuste entre o fundamento da moral e a sua ação concreta, que aflora a criação e a produção da subjetividade, de sorte que o indivíduo, na consecução de um trabalho ético, atue como autor de si mesmo.

Recusando-se a fundamentar a possibilidade de modelos de uma moral absurda, o que não seria plausível, porquanto a conduta absurda não fixa regras num horizonte extra-humano, o que a transformaria numa moral transcendente, Camus póe em cena certas figuras que, certamente, não se revestem de exemplaridade, mas, de certo modo, vêm fundamentar e ilustrar a descrição camusiana de uma ética da absurdidade ou as formas de assujeitamento ante a moral absurda. É assim que o autor alude, no ensaio, a certos tipos humanos que, privados de futuro e cônscios da falta neles inscrita, almejam a inserção máxima da vida, inventando uma forma singular de viver, uma existência estilizada.

A primeira ilustração da moral absurda que prescinde do amanhã e nada espera, Camus a situa na figura de Don Juan. Nessa personagem, a renúncia ao absoluto, ao ideal de um mundo unívoco, é evidente; sua paixão consiste na multiplicidade, sua meta é a vida em sua variabilidade. Disso decorre o seu amor visceral não a uma mulher, mas a todas elas. A vitalidade intensa desse afeto impóe que ele seja vivido sistematicamente, com a mesma profundidade e o mesmo desprendimento, uma vez que o amor único e absoluto, aquele que enfim preencherá o vazio que dilacera todas as almas, inexiste. Para Don Juan, "[...] o lamento do desespero perdido no deleite, esse lugar comum da impotência não lhe pertence" (CAMUS, 2004, p. 84). As possibilidades todas que a vida oferece devem ser vivenciadas ao máximo. Eis a sabedoria do donjuanismo, a qual coincide com a do homem absurdo. No encalço de prazeres múltiplos, a obsessão dessa personagem, seu problema nodal, sua única preocupação, assevera Camus, consiste na eficácia de sua estratégia. Enquanto sedutor consciente, pratica uma ética da quantidade que visa a haurir as possibilidades todas, que para ele se traduzem em cada uma das mulheres. Nesse registro, é dupla a rejeição dessa personagem, que se evade do sonho de redençáo futura e, concomitantemente, se emancipa da nostalgia 
de um passado que conteria o elo perdido da unidade. $O$ ideal do amor eterno figura, por conseguinte, como correlato da representação absoluta, do reencontro da unidade perdida.

A postura dessa personagem não desdenha, contudo, o encantamento que exala desse horizonte. Camus argumenta que Don Juan é cônscio acerca da coincidência entre esse ideal e o clamor que ressoa dos confins de sua alma; ele não ignora os anseios que reverberam por suas entranhas. Não obstante, a despeito da força do desejo que sente em si, é lúcido quanto à intangibilidade dessa esperança ou dessa obsessão, que pode conduzir à trapaça, visto que a busca desse amor totalitário é também uma forma de saltar para fora do registro do absurdo. Ainda que não minimize a emoçáo que pode advir da persecução dessa forma idealizada de amor, essa personagem sabe que tal esperança não é crucial e adivinha seus perigos:

[Don Juan] Sabe muito bem: aqueles que são afastados de toda a vida pessoal por um grande amor talvez se enriqueçam, mas certamente empobrecem os escolhidos pelo seu amor. Uma mãe, uma mulher apaixonada têm necessariamente o coração seco, porque afastado do mundo. Um único sentimento, um único ser, um único rosto, mas tudo acaba devorado. (CAMUS, 2004, p. 66).

O amor que mobiliza esse espírito aventureiro nada tem de monista; Don Juan persegue uma experiência amorosa que envolve todos os rostos possíveis e, concomitantemente, sente em si o terrível frêmito de sua própria perecibilidade. Assim, a cada nova experiência amorosa, essa figura literária vive um verdadeiro renascimento que reestrutura sua vida: "Amar é possuir, conquistar e esgotar, eis sua maneira de conhecer” (CAMUS, 2004, p. 88).

O gozo da vida, insiste o ensaísta, não emancipa essa personagem dos desígnios preconizados por um destino que o ultrapassa e chancela sua derrota antecipada, ou seja, o envelhecimento e a morte: "Don Juan está preparado para isso. O que esta [a morte] pressagia não é nenhuma surpresa. Ele é consciente dela na medida em que não oculta de si mesmo o seu horror" (CAMUS, 2004, p. 81).

Por esse prisma, aludindo aos cruéis desenlaces atribuídos à história dessa personagem, Camus considera que todos eles apresentam extrema logicidade numa vida que elegeu como meta a persecução da alegria sem futuro. O donjuanismo resulta, pois, numa conduta coerente com a ética 
absurda, para a qual a fruição de uma felicidade maximizada tem como reverso um destino inexorável e trágico.

As ações do conquistador cujo espírito não se diferencia do aventureiro - outra ilustração camusiana -, visa ainda à vitória, mas sabe que ela jamais se efetuará de maneira definitiva. Seu protesto, sua revolução é ainda contra o inexorável; todavia, sabe que sua revolta é vã e nada poderá contemplá-la ou resolvê-la, visto que nenhuma conquista ou vitória impedirá que ele seja ultrapassado por forças vertiginosas. Destarte, o horizonte da conquista não transpóe o humano e as contradiçóes que o definem. Daí que os desejos desse homem obcecado em seduzir e conquistar não remetam ao sonho de uma outra vida, a um ideal de felicidade que suprima a cesura entre o pensamento e o ser. Ele deseja, sem dúvida, mas os objetos de desejo por ele perseguidos consistem todos em realizaçóes deste mundo, que não transcendem nem as máculas, nem a dor de sua condição. Aos seus olhos, as paixôes e o sentidos mais pungentes concernem ao humano, ao drama que as relaçóes humanas entretecem no âmbito de uma vida transitória, fugaz, mas bela:

Como náo entender que, nesse universo vulnerável, tudo o que é humano e apenas humano adquire um sentido mais ardente? Rosto tenso, fraternidade ameaçada, amizade táo forte e táo pudica dos homens entre si, exalta as verdadeiras riquezas, porque são perecíveis. (CAMUS, 2004, p. 83).

Nesse sentido, Don Juan, o sedutor, o conquistador, é livre porque ilumina com sua inteligência o deserto em que vive. Eis novamente Camus enaltecendo a consciência lúcida que definitivamente não cede à paixão que dilacera e, justamente por essa razão, logra o experienciar de uma liberdade tangível e radicalmente ampliada.

O homem cotidiano, argumenta o autor, é apressado, não gosta de se demorar. A multiplicidade das coisas náo lhe interessa, porquanto vive no encalço de sua obsessão: a esperança, qualquer que seja ela. Nessa busca frenética, os desvios, os deslocamentos solicitados pelos detalhes do mundo, tudo o que solicita um olhar e um pensar mais concentrados é negligenciado. Nessa vertente, a figura do ator - mais propriamente a do ator-comediante - simultaneamente contemporiza com o homem absurdo e demarca sua distância imensurável do homem comum. Notadamente, assinala Camus, não se trata de supor uma vinculaçáo inexorável entre o homem absurdo e os atores em geral; entretanto, tomando o ator em seu tipo ideal, a peculiaridade 
daqueles que fazem do palco sua escolha reside num "[...] destino absurdo que poderia seduzir e atrair um coraçáo clarividente” (CAMUS, 2004, p. 91). Advoga Camus:

Para o ator, tanto quanto para o homem absurdo, uma morte prematura é irreparável. Nada pode compensar a soma de rostos e séculos que, sem ela, teria percorrido. Mas, de toda maneira trata-se de morrer. Pois o ator está em toda parte, sem dúvida, porém o tempo também o arrasta e exerce sobre ele seu afeto. (CAMUS, 2004, p. 97).

Nessa perspectiva, Camus entrevê na figura do ator-comediante a lucidez de saber que tudo converge para o ocaso; por isso, sua aspiração maior consista no gozo da representação, a qual se esgota em si mesma porquanto seu significado não advém de um ideal indefinidamente postergado. Noutros termos, o ato de representar, em definitivo, náo consiste numa fase a ser cumprida para o alcance de uma meta ou de uma utopia de felicidade; não se trata tampouco de uma obra cuja fixidez venha ancorar solidamente a existência daquele que a produziu. Novamente, Camus: "O ator nos deixará no máximo uma fotografia, e nada do que era, seus gestos, seus silêncios, sua respiração curta ou seu hálito amoroso chegará até nós" (CAMUS, 2004, p. 92). A absurdidade impregna essa figura; tal como Don Juan e o conquistador, o que nutre seu espírito não é a esperança de algo que venha lastrear a existência, perenizando-a, mas antes as glórias perecíveis, criaçóes passageiras e efêmeras.

A completude e a variabilidade das vidas encenadas por um ator exauremse em temporalidades exíguas, nas quais vidas múltiplas, espíritos diversos, são encarnados e vivenciados enquanto possibilidades concretas de vida, razão pela qual Camus os denomina viajantes das almas. Flanar por vidas alheias, que ultrapassam a singularidade de sua situação concreta, arrasta consigo a experiência dessas subjetividades outras que ele representa, fecundando e alargando a amplitude de sua própria subjetividade. A experiência desse artista vem ao encontro da máxima do absurdo, qual seja, a moral da quantidade, da vida intensa, da entrega apaixonada às experiências com as quais se depara. $\mathrm{O}$ talento daquele que representa revela-se exatamente na capacidade de substancializar, no interior de seus estreitos limites, que são os de todos nós, sofrimentos e obscuros desígnios reservados a um destino excepcional, em relação ao qual, enquanto homem comum e cotidiano, permaneceria para sempre aquém. Salienta Camus: 
E o que ele demonstra, sempre ocupado em figurar melhor, é até que ponto o parecer faz o ser. Pois sua arte é isto, fingir totalmente, entrar o mais fundo possível em vidas que não são a dele. Ao cabo desse esforço fica clara sua vocaçáo: aplicar-se de corpo e alma a náo ser nada e a ser muitos." (CAMUS, 2004, p. 93).

Ademais, o teatro revela-se como âmbito fecundo para a expressáo da absurdidade porque nele fundem-se o espírito e a matéria, o físico e as paixões da alma. Os segredos e os mistérios dos afetos só adquirem visibilidade nos gestos corporais: "A lei dessa arte quer que tudo cresça e se traduza em carne" (CAMUS, 2004, p. 94). Daí que, ao encarnar seus personagens, o ator dê vida aos seus fantasmas indizíveis.

Cumpre ratificar: ao recorrer a essas ilustraçôes, Camus não está a propor um código moral que venha reger a conduta individual por vias heterônomas; completamente outro o seu registro. A atitude absurda em todas as suas variantes solicita disciplina, dedicação e o árduo reconhecimento de que essa conduta - que se confunde com uma obra - não possui lastro que lhe garanta um significado último, uma razão que venha justificar o esforço desse constructo. É difícil perseverar nessa postura; mesmo para o sedutor/ conquistador, mesmo para o ator - e também para o artista, para o literato, outras variaçóes da conduta absurda - a gratuidade da vida pode se ofuscar, de modo que eles se tornem vulneráveis, cedendo a um ideal de absoluto. Manterse no absurdo exige o assentimento de que a obra náo desvela transcendência alguma. Pelo contrário, é sobre a falta de significado e sobre o absurdo da existência que ela se edifica. À conduta que não salta, subjaz o olhar sóbrio acerca da fatalidade necessária que a todos nos espreita; em sua assunção do absurdo, ela instaura um mundo essencialmente humano, o qual já não se nutre da expectativa de que seja possível reencontrar o elo perdido entre o homem e o mundo.

Destarte, a proposta camusiana se afasta com veemência da noção clássica de moral e, simultaneamente, aproxima-se consideravelmente da noção de prática de si desenvolvida por Foucault. Na moral absurda, não é o código externamente sistematizado que prevalece como fonte irradiadora das condutas, sancionando-as coercitivamente. Pelo contrário, essa moral se erige nas formas de subjetivação. Além disso, é também num aspecto outro que a ética absurda, guardadas as proporçóes, se aproxima da ética greco-latina, tal como perscrutada por Foucault. Em ambas, estabelece-se o paralelo entre a arte 
e a vida; em ambas, a conduta humana figura como uma estética da existência. Vimos que o intuito de Foucault é apreender esse aspecto na conduta sexual dos gregos, procurando entrever de que modo certas técnicas de vida, certos exercícios do corpo e da alma viabilizam a construção de si. Inequivocamente, a despeito de sua ênfase numa necessária disciplina, não encontramos nada similar na fundamentação que Camus tece a respeito da noção de moral absurda. Não obstante, para Foucault, as formas de subjetivação conduzem a um sujeito moral que constrói sua conduta, erigindo sua subjetividade como uma obra, visando a dar a ela a beleza e a forma da obra de arte. Os autores se encontram também nesse ponto.

A conduta absurda, ao ser erigida com base em determinaçóes fundamentalmente subjetivas e norteada apenas pelos preceitos gerais dessa moral, conduz o indivíduo a empenhar-se na construção de si num mundo que o privou dos lastros objetivos. A adesão à moral absurda - ou à ética que incorpora o trágico - com uma conduta estilizada em formas distintas e múltiplas, mas iguais em seu valor, consiste num modo de permanecer à altura da dignidade humana numa luta em que o homem, "vencido de antemão", não vislumbrará a vitória jamais. Dessa forma, atitude absurda conduz a uma ética que se consuma em diferentes modos de subjetivação engendrando um estilo e, portanto, uma estética da existência. O sentimento da revolta ante o desamparo absoluto do homem alarga - e impóe - a liberdade de inventar diferenciados modos de ser, uma vez que a forma da subjetividade não está previamente moldada numa moral heterônoma, seja ela laica ou religiosa. O homem absurdo, esse conquistador de horizontes sem futuro, com seu sucedâneo de aventuras, opóe-se diametralmente ao regozijo do homem cotidiano, que cultua seus grilhóes. Nessa senda, as figuras escolhidas por Camus, efetivamente ilustram uma postura absurda. Trata-se de figuras trágicas; elas sabem da impossibilidade de superar os vaticínios, da inutilidade de investir contra o destino, mas não desistem do esforço da figuração, da criação que pode transmudar o mundo, certamente não no que concerne à sua essência, mas dotando-o de uma nova forma, uma nova configuração, ainda que inequivocamente fictícia.

Consequentemente, tal como os gregos, o homem dotado da consciência absurda necessita inventar sua vida, sua subjetividade, o que exige também a singularizacão de sua atitude em face dos eventos cotidianos. Ao proceder assim, ele estiliza sua conduta: 
Transposto para o interior da escrita de quem contempla a própria vida e procura expressar sua própria intuição do absurdo, esses exemplos de estilização transformam-se em invenção de si. Viver expressando o absurdo será a forma de duplicar a existência, de corrigi-la sem jamais negar o impulso que impele à criação? (PINTO, 1988, p.160).

Por essa razão, Camus insiste no caráter criador dos tipos absurdos por ele mencionados. Eles instauram uma forma original de ser, uma arte da existência, compromissada fundamentalmente com sua lucidez e com sua revolta. Essas ilustraçóes correspondem a formas de assujeitamento as quais compartilham a mesma substância ética que impóe a construção/invenção de si, operando uma metamorfose da subjetividade, no dizer deleuziano, e convergindo para a elaboração de um estilo, para uma estetização da existência. Evidentemente, a ética absurda não vem secundada pela necessidade de fazer da vida individual um exemplo a ser apreciado; nesse caso, o compromisso é com a vida e com a liberdade, de maneira que a vivência do múltiplo, a afirmação da diferença, sejam efetivamente consumadas.

Ademais, a assunção da absurdidade é contemplada com a experiência de uma felicidade efetivamente humana, a qual não visa a abolir a tragicidade inscrita em nossa condição. Em termos camusianos, a tragédia se expressa tanto no esforço criador que resulta na obra de arte quanto numa atitude que atribui uma forma estilizada à existência. Com imagens múltiplas e inesgotáveis seja na obra, seja na conduta -, encena-se, em profundidade, o drama da existência, do qual uma consciência lúcida não pode e não deseja escapar: "Não mais a fábula divina que diverte e cega, mas o rosto, o gesto e o drama terrenos em que se resumem a difícil sabedoria e uma paixão sem amanhâ" (CAMUS, 2004, p. 133). A ética absurda, porque dissidente das promessas de felicidade que promovem a consonância entre os desígnios humanos e os movimentos da vida, instaura-se nesse descompasso mesmo e, a partir dele, logra apreciar e fruir plenamente o espetáculo mundano. Uma vez disponível para as experiências que esse espetáculo generosamente lhe oferta, a conduta que aí aflora, além de assumir a multiplicidade como norte de persecução, é permeada por um impulso criador.

Nessa senda, a proposta de uma conduta ética se enlaça com um registro estético, de sorte que a moral absurda coincida com a arte. Sob essa perspectiva, como entre os gregos, o homem que assente sua tragicidade torna- 
PAIVA, R.

se autor de si mesmo. Resta-lhe, pois, a alternativa da criação: compete a ele postar-se ante a sua vida como um artista ante sua própria obra.

PAIVA, Rita. Human precariousness and stylized existence. Trans/Form/Ação, Marília, v. 36, n. 1, p. 117-136, Jan./Abril, 2013.

\begin{abstract}
This article discusses the helplessness experienced by the consciousness vis-à-vis the absence of solid bases for its longings for happiness and for its symbolic representations. For this purpose, the object of reflection of the article is one of Albert Camus' philosophical essays, The Myth of Sisyphus, and we inquire into the possibility of an ethics that stylizes life without minimizing the painful precariousness of human existence. Making reference to certain texts by Foucault, we attempt to establish possible connections between Camus' ethics and an ethics of the aesthetics of existence as found in the thinkers of ancient Greece.
\end{abstract}

KEYWORDS: Absurd. Absurd. Aesthetics. Ethics. Existence.

\title{
REFERÊNCIAS
}

ALVES, Marcelo. Camus: entre o sim e o não a Nietzsche. Florianópolis: Letras Contemporâneas, 2001.

BRANDÃO, Junito de Souza. Mitologia Grega. Petrópolis: Vozes, 2000, v. 1.

CHAMPIGNY, Robert. Esthétique et morale. In: FITCH, Brian T. (Org.). La revue des lettres modernes, n. 9, Éditions Lettres Modernes, Paris, 1965.

CHAUÍ, Marilena, Introdução à História da Filosofia, São Paulo: Companhia das Letras, 2002.

CAMUS, Albert. A inteligência e o cadafalso e outros ensaios. São Paulo: Record, 2002.

. O Mito de Sisifo. Rio de Janeiro: Record, 2004.

DELEUZE, Gilles. Foucault. São Paulo: Brasiliense, 1988.

ESCOBAR, Carlos Henrique de. A genealogia (Foucault) ou os "leninismos" na materialização de uma política nietzschiana. In: FOUCAULT, M. Dossier. Rio de Janeiro, Graal, 1984.

FOUCAULT, Michel. Dossier: Últimas entrevistas. Rio de Janeiro: Taurus, 1984. . O uso dos Prazeres. Rio de Janeiro: Graal, 1988. 
GONZÁLEZ, Horácio. Albert Camus: A libertinagem do Sol. São Paulo: Brasiliense, 1983. MAUROIS, André. De Proust a Camus. Rio de Janeiro: Nova Fronteira, 1965.

NIETZSCHE, Friedrich. A Gaia Ciência; Sobre a verdade e mentira. São Paulo: Abril, 1973. (Coleção Os Pensadores).

O nascimento da tragédia ou helenismo e Pessimismo. São Paulo: Companhia das Letras, 2005.

PINTO, Manoel da Costa. Albert Camus: um elogio do ensaio. São Paulo: Ateliê, 1998. 2002. Introdução. In: A inteligência e o cadafalso e outros ensaios. São Paulo: Record,

VALDANO, Juan. Humanismo de Albert Camus. Cuenca: Universidade Católica de Cuenca, 1973. 
PAIVA, R. 